\title{
ADDITIVES AND PREMISES USED TO OBTAIN HIGH QUALITY SILAGES
}

\author{
CESAR NETO, José Maria ${ }^{1}$ \\ SANTOS, Betina Raquel Cunha dos ${ }^{1}$ \\ PERAZZO, Alexandre Fernandes ${ }^{1}$ \\ SILVA, Alex Lopes da ${ }^{1}$ \\ SANTOS, Francisco Naysson de Souza ${ }^{1}$ \\ PEREIRA, Danillo Marte ${ }^{1}$ \\ MACÊDO, Alberto Jefferson da Silva ${ }^{2}$ \\ SANTOS, Edson Mauro ${ }^{1}$
}

\begin{abstract}
SUMMARY: The use of additives in silages is increasing worldwide, based on the premise of the better material preservation or because of an aggregation of nutritional value with the use of some types of additives. This review aims to present information on a series of additives that can be used in a variety of silages according to their needs. The main classes of additives currently available are: fermentation inhibitors, nutrients, aerobic deterioration inhibitors, fermentation stimulants and humidity absorbent additives. It is fundamental that the properties adopt the practice of producing quality roughage as a primary investment, aiming on a greater financial return through the adoption of strategic planning in the short, medium and long term. There are several additives available in the market, but it is ideal to know if its use in the silage is necessary, what is the form of application, its dosage, and how the additive will benefit the silage. Thus,, it is essential the search for additives that gives additional contribution to the microorganisms responsible for the potentialization of the fermentation of the substrates present in the biomass, aiming to bring benefits to the fermentation process, to reduce losses, to stimulate or inhibit fermentations, to keep the stability of the forage, and to preserve the nutritive value of the ensiled mass in order to be similar to the green forage, or as close as possible to the plant it came from, or to add nutritional value through certain classes of additives.
\end{abstract}

Keywords: Aerobic stability, Forage, Microorganisms, Planning, Roughages.

\section{ADITIVOS E PREMISSAS UTILIZADAS PARA OBTENÇÃO DE SILAGENS DE ALTA QUALIDADE}

RESUMO: É crescente a utilização de aditivos em silagens em todo o mundo, partindo da premissa de uma melhor preservação do material ou em razão de uma agregação de valor nutricional com o uso de alguns tipos de aditivos. Esta revisão objetiva apresentar informações sobre uma série de aditivos que podem ser utilizados nas variadas silagens de acordo com sua necessidade. As principais classes de aditivos disponíveis atualmente se enquadram como: inibidores de fermentação, nutrientes, inibidores de deterioração aeróbia, estimulantes de fermentação e os aditivos absorventes de umidade. É necessário que nas propriedades seja adotada uma postura de produzir volumosos de qualidade como um investimento primário, pensando em um maior retorno financeiro através da adoção de um planejamento estratégico a curto, médio e longo prazo. Há uma série de aditivos disponíveis no mercado, o ideal é saber se é necessário utilizar aditivo na silagem, qual o modo de aplicação, sua dosagem, e como o aditivo beneficiará a silagem. Dessa forma é primordial essa busca por aditivos que dê aporte adicional aos microrganismos responsáveis pela potencialização da fermentação dos substratos presentes na biomassa, visando trazer benefícios ao processo fermentativo, reduzir perdas, estimular ou inibir fermentações, manter a estabilidade da forragem, preservar o valor nutritivo da massa ensilada para que seja semelhante ao da forrageira verde, ou o mais próximo possível a planta que lhe deu origem ou agregando valor nutricional através de determinadas classes de aditivos.

Palavras-chave: Estabilidade aeróbia, Forragem, Microrganismos, Planejamento, Volumosos.

\footnotetext{
${ }^{1}$ Federal University of Paraíba, Areia, Paraíba- Brazil. Department of Zootecnia

${ }^{2}$ Federal University of Viçosa, Minas Gerais - Brazil. Department of Zootecnia
} 


\section{INTRODUCTION}

Silage is a forage storage method based on the fermentation of the substrates under anaerobic conditions and low $\mathrm{pH}$, because under these conditions only lactic acid bacteria (LAB) can control the fermentation and reduce the $\mathrm{pH}$ through the conversion of soluble carbohydrates in organic acids, releasing carbon dioxide, water and energy in the form of heat, promoting the elevation of the material's temperature and reduction of the $\mathrm{pH}$ (ZANETTE, 2010).

Kung Junior (2010) points out that in some silages the fermentation process can be quite uncontrolled, leading to a poor preservation of the material, and because of that, additives for silage were developed aiming to improve the fermentation process, regarding the energy content as well as the dry matter recovery, with subsequent improvements in animal performance being observed.

Whatever the forage crop is, there is a range of autochthonous microorganisms that coexist harmoniously with it, and after the breakdown of the cellular content and release of substrates due to forage processing during the ensiling process, there is a satisfactory growth of these microorganisms, and it is extremely important to understand that both the autochthonous microorganisms in the silage and the conditions of the environment contribute to the preservation of the forage, inhibiting the performance of undesirable microorganisms. However, there will be a change in the microbial population as a function of the passage from the aerobic medium to the anaerobic stage, where both anaerobic and facultative anaerobic microorganisms will be present (MUCK, 2010).

However, with the change of the medium, the growth and predominance of LAB is favored in the whole silage, in such a way that the undesirable microorganisms have their action inhibited and the result will be a stable silage with low $\mathrm{pH}$. Nowadays, there is also a wide range of microbial additives that improve the efficiency in silage preservation. It is also important to know how they change the fermentation, preservation and the use of silage by animals (MUCK, 2010). The use of microbial additives in well-produced silages promotes additional gains to the process (SCHMIDT; SOUZA; BACH, 2014).

According to Santos and Zanine (2006) LAB are well diversified in the material to be ensiled, mainly represented by the species: Lactococcus such as Lactococcus lactis, Enterococcus faecalis, Pediococcus acidilactici and Leuconostoc mesenteroides, and Lactobacilli (Lb.) such as Lb. plantarum and Lb. cellobiosis, controlling the action of aerobic microorganisms. 
Sousa, Silva and Oliveira (2011) emphasize that it is fundamental to examine the results achieved through the adoption of a certain technological practice that will intervene in the productive process in order to reduce losses and increase the efficiency of the available resources, since the advances already established emphasize on overcoming the new challenges and prospects, aiming at the real success in the practice.

Regard the establishment of research protocols with additives, Schmidt, Souza and Bach (2014) emphasize that the technical and economic efficiency of the products should be considered, as well as the optimization of the doses, since research work guiding the best way of practical application of additives in the properties. The decision making about which additive to choose for use in each type of silage is hampered by the high variability in the experimental results. Schmidt (2008) emphasizes that a set of experimental trials would be necessary to evaluate the response to the use of a particular type of additive, highlighting these evaluations through the integration of the results by the technique of meta-analysis.

Therefore, the application of additives to the forage at the time of ensiling aims to improve the fermentation process, to reduce losses, to promote or inhibit fermentations, to preserve the nutritive value of the ensiled mass in order to be similar to the green forage, or as close as possible to the plant it came from, or to add nutritional value through certain classes of additives.

\section{CHARACTERIZATION OF THE PROBLEMS INHERENT TO THE MAKING OF POOR-QUALITY SILAGES, CLASSIFICATION OF ADDITIVES AND BENEFITS}

A poor quality silage, resulting from poor sealing, holes in the plastic film, high humidity, low nutritional value of the forage or contamination of the material, support the development of deleterious microorganisms by continuing the secondary fermentations, either by enterobacteria, filamentous fungi, clostridia, strains, yeasts or bacilli (MUCK, 2010), which result in unstable silages and may also lead to sanitation problems, and depending on the environmental conditions, there will be room for the development of other opportunistic pathogenic microorganisms (Escherichia coli, Fusarium verticillioides, Clostridium botulinum and Aspergillus flavus), causing harmful effects on animal's health and performance (OGUNADE et al., 2018).

Additives are classified in the 5 main groups for use in silages according to McDonald et al. (1991), which are: fermentation inhibitors (acids, salts and other chemical inhibitors), nutrients (urea, ammonia, grains, minerals, citrus pulps) aerobic deterioration inhibitors (acetic, caproic and ammonic acid, among others), fermentation stimulant (acid lactic bacterial cultures, enzymes and sources of carbohydrates) and moisture-absorbing additives. A silage additive is 
only effective when it presents positive results regarding the recovery of the dry matter, decreases heating and molding during storage and feeding or in the case of use of a nutrient additive that improves animal performance [milk (quantity or composition), weight gain, body condition, reproduction] (KUNG JUNIOR, 2010).

In the ensiling process, additives may be used to improve fermentation and contribute to preserve the nutritive value of the ensiled mass. There are several sources of additives available in the market. In Brazil, according to Bernardes (2008), the main additives used in the production of silages are the bacterial inoculants, the chemicals (urea, virgin lime, buffered acids) and the moisture absorbents. The same author also points out that there is a variation in the response of the silage due to the use of a certain type of additive because its efficiency is determined based on the dosage used, on the quality of the forage or even on the species of bacteria used, in the case of bacterial inoculant. In addition, it is essential to standardize the application of the additive throughout the mass to be ensiled for satisfactory results.

According to Adesogan (2014), silage additives can be used to reduce losses of dry matter (DM) and excessive heating caused by deleterious microorganisms. Understanding the efficiency and the role of the different types of additives is essential to achieve the desired improvements in silage preservation. For the use of any type of additive it is necessary to follow well defined criteria, knowing when to use an additive, why to use the specific additive, how the application should be done, and finally, how the additives in question work and interfere in the process, but the ideal would be to look for a professional who would help in this decision-making, since producers are often influenced by lay or commercial information (SCHMIDIT; SOUZA; BACH, 2014). The efficiency of a particular additive can be influenced by the characteristics of the species used, the temperature and mass $\mathrm{pH}$, the soluble carbohydrates content and the population of epiphytic microorganisms (ITAVO et al., 2010).

\section{MICROBIAL ADDITIVES}

\subsection{Homofermentative and heterofermentative bacteria}

Through the use of microbial inoculants, it is possible to reduce cellular content losses, which are mainly soluble carbohydrates, proteins and organic acids, what increase the digestibility, and therefore the nutrient and energy recovery of the forage, which leads to better performance of the animals (BASSO, 2009). Thus, several factors can interfere with the efficiency of the additive, such as characteristics of the species used, temperature and $\mathrm{pH}$ of the 
mass, soluble carbohydrate content and population of epiphytic microorganisms (ITAVO et al., 2010).

Zopollatto et al. (2009) present a class of additives widely employed in the production of silages and strongly studied currently, which are the microbial additives, including homofermentative and heterofermentative bacteria, or the combination of both. Forage fermentation is totally dependent on the types of microorganisms that can control the process. The faster fermentation rate, lower proteolysis, higher lactic acid concentration, lower contents of acetic and butyric acids, lower ethanol content, and higher recovery of energy and dry matter are characteristics observed when homofermentative microorganisms are used, whereas heterofermentative bacteria tend to use lactic acid and glucose as source of substrate for the production of acetic and propionic acids, which are effective in the control of fungi, under low $\mathrm{pH}$.

According to Oliveira et al. (2011) the association between inoculants that have homolactic and heterolactic strains of bacteria causes a so-called ferulic acid esterase enzyme to be produced, which makes it possible to break the bonds between lignin and carbohydrates of the cell wall and, consequently, to improve the digestion of fiber. Carvalho et al. (2014) emphasize the importance of using strains of lactic acid bacteria specific for each type of material to be ensiled, due to the variety of behaviors presented during the fermentation of carbohydrates over the entire ensiling period.

The inoculation of homofermentative bacteria in the silage of forage crops promotes a fast start of the fermentation process, since the medium domain is uniform, where the microorganisms act consuming the substrates present, quickly increasing the production of lactic acid, with a fast reduction of the medium $\mathrm{pH}$ and which along with the low oxi-inhibition reduction potential of enterobacteria and bacteria of the genera Listeria, Bacillus and Clostridium result in wellfermented silages, however, this outcome depends on the availability of sufficient fermentative substrate for their development (TABACCO et al. 2009; FERREIRA et al., 2013).

Regarding the use of heterofermentative bacteria, several studies aim to create a positive balance between fermentation, aerobic deterioration and animal performance, producing acetic and lactic acid, which together are able to control deleterious microorganisms that can develop in anaerobic and aerobic environments (HUISDEN et al., 2009; SANTOS, 2012). In addition, the acetic acid produced by the heterofermentative LAB has an antifungal effect, which inhibits the growth of yeasts and filamentous fungi when the silage is exposed to the air, potentiating the joint action with the lactic acid (KUNG JUNIOR, 2008).

Sousa et al. (2008) evaluating the effect of microbial inoculants on fermentation in sugarcane silages, found that even though the combination of strains of homofermentative and 
heterofermentative bacteria did not decrease the yeast population present in the silages, it was efficient reducing their activity, thus reducing gas losses and recovering more dry matter. Mendes et al. (2008) emphasize the importance of reducing the yeast population or even inhibiting its action because these microorganisms cause alcoholic fermentation, producing two molecules of ethanol, two molecules of carbon dioxide and two molecules of water from each molecule of glucose, causing great energetic loss of the forage and rejection by the animals.

The intense recurrent alcoholic fermentation when ensiling pure sugarcane is a major obstacle for this crop's silage, in detriment of the large yeast population naturally present in the material, which are the main microorganisms capable of fermenting the soluble carbohydrates contained in the non-fibrous carbohydrates fraction. By using additives that allow the inhibition of the activity of these yeasts, the residual soluble carbohydrates content will be higher in the silage and, consequently, the non-fibrous carbohydrates content will also be higher (LOPES; EVANGELISTA, 2010).

Without the use of additives in the sugarcane silage, a bad fermentation occurs due to the disappearance of soluble carbohydrates present in the cellular content of sugarcane and the high production of ethanol by epiphytic yeasts present in the green forage. The search for additives for sugarcane silage that are capable of inhibiting the growth of yeasts, reducing the ethanolic fermentation and thus the losses of dry matter, in addition to providing an increase in aerobic stability, is increasing. Recent assessments using virgin or hydrated lime and heterofermentative lactic acid bacteria in sugarcane silage have shown to be promising for reducing alcoholic fermentation and dry matter losses (MOHALLEM et al., 2013).

The variations in the results from the use of combined microorganisms as inoculants in the silage would not be surprising due to the wide range of different species with variations in the relative inclusion rates of species within inoculants and with the existence of differences between strains of a given species (MUCK et al., 2018).

According to the same authors, the use of combined compulsory and facultative heterofermentative lactic acid bacteria strains in inoculants aims to achieve the triggered benefits of both types of microorganism in a single product, since the facultative heterofermentative LAB would act to control the initial period of active fermentation, suppressing enterobacteria, clostridia and other microorganisms, thus reducing the losses of proteolysis and fermentation of DM, whereas with the effect of compulsory heterofermentative LAB, in most cases L. buchneri, there would be slowly conversion of lactic acid into acetic acid after the period of fermentation of the active silage, raising the $\mathrm{pH}$ and improving the aerobic stability of the silage. 
Siqueira et al. (2010) working with raw and burned sugarcane silage with and without additives, testing chemical and microbial additives, concluded that the use of additives is a strategy that can avoid high losses, where the microbial additive Lactobacillus buchneri was the one that acted most satisfactorily in the fermentation and post-opening phases of raw or burned sugarcane silages, by reducing gas loss and for being efficient in the aerobic stability of the silage.

Kung Junior (2010) highlights Lactobacillus plantarum, L. acidophilus, Pediococcus acidilactici, P. pentacaceus and Enterococcus faecium as the most common homofermentative lactic acid bacteria used in the production of microbial inoculants. The same author also points out that it is common for microbial inoculants to contain one or more of these bacteria that have been selected for their ability to control the fermentation because of their potential synergistic actions. For example, the growth rate is faster in Streptococcus $>$ Pediococcus $>$ Lactobacillus. However, some strains of Pediococcus tolerate higher DM conditions than Lactobacillus in addition to having a broader range of ideal temperature and $\mathrm{pH}$ for growth.

Zopollatto et al. (2009) state that in order to be successful in the use of microbiological additives in silages, there are three main factors: it depends on the ability of the inoculated bacteria to grow fast in the ensiled mass, the presence of adequate substrate and the population of bacteria inoculated in relation to the epiphytic population of the forage. Using microbial additives carrying viable LAB cells will help increase the populations of naturally occurring lactic bacteria present in the silage, improving the fermentation profile in the silo. In the literature there is a great deal of variation in the results when it comes to the use of inoculants in silages. However, when applied correctly, along with an adequate silage management, silages of excellent quality are achieved (MUCK, 2010).

Zopollatto et al. (2009), mention the great diversity of homofermentative (Lactobacillus plantarum, Lactobacillus curvatus, Lactobacillus acidophilus, Lactobacillus spp., Streptococcus faecium, Pediococcus pentosaceus and Pediococcus acidilactici) and heterofermentative bacteria (Lactobacillus buchneri, Lactobacillus brevis and Propionibacterium) used in inoculation, or the mixture of hetero and homofermentative, and in some commercial products there is still the inclusion of enzymes (amylase, cellulase, hemicellulases) in the inoculant.

There are a number of groundbreaking research to investigate bacterial strains with potential of use as microbial inoculants, including Streptococcus bovis, Propionibacterium acidipropionici, bacillus and yeast species. Since $S$. bovis is not as resistant to very acidic environments as lactobacilli, there is a decline in its population after the active fermentation phase. The use of Propionibacterium-based inoculants, causing the production of propionic acid improves aerobic stability (MUCK et al., 2018). Propionibacterium bacteria have the ability to 
convert lactic acid and glucose into propionic acid and acetic acid, antifungal compounds (MARI, 2016).

Bonaldi (2017) points out the use of certain strains of Bacillus subtillis bacteria as potential inoculants for silages, given their antifungal and antibacterial ability, since it is possible to use the biological control of undesirable microorganisms, thus increasing stability in the silages. Basso et al. (2012) observed beneficial effects of Bacillus subtilis on the aerobic stability of corn silage through yeast and fungi control. Bacillus subtilis, for producing acetic acid and different metabolites with antifungal and antibacterial activity, including antibiotics, enable the biological control of phytopathogens during silage unloading (LANNA FILHO et al., 2010; BASSO et al., 2012; LARA et al., 2015). Within the genus Bacillus, Bacillus subtilis according to Todovora and Kozhuharova (2009) is one of the most important producers of metabolites with antifungal and antibacterial activity.

Basso et al. (2012) evaluated the fermentation characteristics and aerobic stability of corn silages inoculated with Bacillus subtilis and reported an increase in the $\mathrm{pH}$ values in all silages, the control and the inoculated ones, and it was verified that the silage inoculated with B. subtilis at the highest level applied $\left(5 \times 10^{5} \mathrm{UFC} / \mathrm{g}\right)$ showed the lowest $\mathrm{pH}$ value (5.53) after 12 days of aerobic exposure, when it was compared to the control silage ( $\mathrm{pH} 6.63$ ), and that is associated to the lower occurrence of deteriorating microorganisms in this silage. The inoculation at this concentration is capable of controlling the growth of undesirable microorganisms, and improving the aerobic stability of the silage. The authors highlight these results as a way of inferring in practice that the silages with the highest stability are associated with lower occurrences of yeasts and filamentous fungi, and this fact is very promising and desired because of the maintenance of the nutritional characteristics and sanitary conditions of the silages for a longer time, keeping the $\mathrm{pH}$ values more stable in the post-opening phase of the silos.

\subsection{Yeasts}

The most unusual inoculant studied is the yeast, since these microorganisms are the main starters of aerobic deterioration in the silage (PAHLOW et al., 2003). However, Muck et al. (2018) point out that there are some yeast species that have beneficial potentialities for use as inoculants, among which may be selected: yeasts that act to inhibit harmful silage microorganisms and growing yeasts that are currently used as microbiophiles of direct feeding for animals.

Yeasts may be potential inoculants as long as they do not interfere with the silage process and forage nutritional value and do not cause changes in lactobacilli populations or aerobic 
stability. From the selection of yeasts that have that potential, several benefits are observed, such as: improvements in silage quality, digestibility and aerobic stability, possibly altering the microbial ecology in the digestive system of ruminants in order to benefit health or production efficiency (DUNIERE et al., 2015). In addition, the same authors warn that yeast inoculated with probiotic properties must tolerate the silage process and multiply during fermentation or exposure to oxygen before feeding, and should not favor the growth of undesirable microorganisms such as filamentous fungi.

During the fermentation process, the incorrect handling of the silo seal, tears on the plastic cover, or some other cause that allows the entry of oxygen into the silo makes it difficult the rapid predominance of lactic acid bacteria because of the competition with unwanted aerobic bacteria. Thus, limits should not be imposed to improve the anaerobic conditions necessary to obtain quality silage. Sofyan et al. (2011) indicate as a way of improving the anaerobic conditions in the silage, the addition of Saccharomyces cerevisiae yeasts. The authors portray in their work with LAB inoculation combined with yeast in grass silage, that in the treatment in which there was the combination of lactic bacteria (L. plantarum) + yeast S. cerevisiae, a reduction in the number of clostridium colonies was observed, indicating that this yeast is capable of producing antibacterial substances, which inhibits the growth of clostridia. This synergism observed with the junction of LAB + yeast $S$. cerevisiae inhibited the growth of clostridia in the silage, tending to be a smaller population than in a treatment of the LAB inoculant alone or without being treated at all. In conclusion, the consortium of lactic acid bacteria inoculant with yeasts consisting of L. plantarum and $S$. cerevisiae in the production of grass silage, increased the in vitro digestibility and fermentability, reducing the clostridium contamination in the silage without negative effect to the production of volatile fatty acids and ammoniacal nitrogen.

Duniere et al. (2015) evaluated in their study three strains of commercial yeast of the genus Saccharomyces acquired from the company DuPont Pioneer culture collection, where 1,700 yeasts were isolated by in vitro screening based on their ability to persist during ensiling, improve digestion, improve fermentation profiles of final products, and increase ruminal $\mathrm{pH}$ in vivo. After 90 days of fermentation, the $\mathrm{pH}$ and $\mathrm{DM}$ content of all silages reduced within a range associated to high quality corn silage, both being fresh forage, moreover, the inoculation with yeasts did not affect the nutritional composition nor the fermentation products in the corn silage. Ethanol contents were low in all corn silages and did not increase as a result of inoculation with Saccharomyces spp. The results presented were consistent with the observation that the inoculants tested did not affect the number of bacteria, yeasts or molds during the silage of 90 days, besides not increasing the deterioration of the silage and did not alter the aerobic stability of the corn silage. 
Corn is the most traditionally used grass and it is considered ideal for silage, however, crops such as sugarcane and elephant grass, for presenting large mass production per area unit and high operational costs consonant to the daily supply, have been widely used, making further research to be necessary (ITAVO; ITAVO, 2008).

Olstorpe et al. (2010) evaluating the hygienic-nutritional quality of wet barley grain and barley inoculated with the biocontrol yeast $P$. anomala, observed that the inoculation with this yeast inhibited the growth of A. strictum, C. macerans and Cryptococcus wieringa, which are other types of yeasts that were naturally present in barley during the harvest but were not identified after inoculation. In addition, the addition of $P$. anomala reduced the number of naturally occurring fungi in stored barley, highlighting that Aspergillus fumigatus, which is a potentially pathogenic fungus, was absent in the inoculated grain. A surprising result was found in the inoculation of the grain with $P$. anomala regarding the number of enterobacteriaceae $(P$. agglomerans and E. coli), which decreased to a level below the detection level (10 UFC/g grains). This is the first report of the inhibitory effect of $P$. anomala on enterobacteriaceae in cereal grains, which is highly important for food hygiene.

\subsection{Streptococcus}

Among the new strains of microorganisms selected for use as potential inoculants for silage fermentation and conservation, Streptococcus bovis is more similar to the LAB strains that are used in inoculants. This species of lactic acid bacteria is found in the rumen and not in the silage, and since it is not as tolerant to low $\mathrm{pH}$ as the lactobacilli, there may be a decline in its population after the active fermentation of the silage, reducing the probability that it enters in the rumen with silage (MUCK, 2018).

Ferreira et al. (2014) evaluating the chemical composition and degradability of nutrients in elephant grass silages inoculated with Streptococcus bovis isolated from the rumen, observed that with the use of this microbial inoculation the use of silage increased and, consequently, favored the microbial population in the rumen, influencing the degradation of silage nutrients, besides exposing an improvement in the fermentative profile and protein value. The effective degradability was estimated considering passage rates of 2, 5 and $8 \%$ per hour. The authors point out that it is necessary to consider the passage rate, since its disuse can overestimate the extent of degradation, as the food particles are subject to passage to the next compartment before being completely degraded.

In this context Jones et al. (1992) point as the strains of Streptococcus bovis as a lactic acid species with great potential as an inoculant for the silage, even being isolated from the 
rumen, since they have characteristics that allow them to act as initial culture in the fermentation process and promote a rapid acidification of the medium, with a specific growth rate $30 \%$ faster than other LAB species used as inoculant for silage.

The rate of $\mathrm{pH}$ reduction is a key factor in inhibiting microbial activity, resulting in lower losses, where the time taken to reduce $\mathrm{pH}$ basically depends on two conditions: the technology employed (particle size, compaction, sealing, etc.) and the intrinsic fermentative capacity of the plant (JOBIM; NUSSIO, 2014).

The action of certain bacteria, such as Streptococcus bovis, favors the production of lactic acid. Lactic acid is a substance with high and constant ionic dissociation, so that it rapidly acidifies the medium and inhibits the pathogenic bacteria (coliform and clostridium groups) that can be present in the ensiled mass. Through the lactic fermentation under anaerobic conditions it is possible to promote an adequate conservation of the silage material, since once the lactic fermentation is established, the losses of dry matter and crude protein decrease, allowing the production of silages of higher nutritive digestibility (FERREIRA et al., 2013). In addition, some strains of Streptococcus bovis produce bacteriocins, which may inhibit the growth of pathogenic bacterial strains (Mantovani et al., 2002).

Ferreira et al. (2011) evaluated the fermentative profile and nutritive value of elephant grass silage inoculated with Streptococcus bovis, using two cultures of this LAB (HC5 and JB1) and observed an increase in lactic acid contents and a decrease in the contents of acetic, butyric and propionic acid, improving the fermentation. In the silage inoculated with Streptococcus bovis (JB1) a reduction in NDF contents, reduction in the ammonia concentration and increase in the silage digestibility was observed, however, there was no statistical difference ( $p>0.05)$ was observed between control and inoculant treated silages containing S. bovis HC5 regarding the NDF content and in vitro digestibility of the dry matter (IVDDM).

Ferreira et al. (2013) inoculated strains of Streptococcus bovis in elephant grass silages, and observed in the inoculated silages, higher levels of dry matter in comparison to the treatment without inoculation, which may be associated to the maintenance of the homofermentative fermentation, where the dry matter losses are lower; in addition, it was observed a higher crude protein content in the inoculated silages, due to the reduction of proteolysis, since the growth of enterobacteria was inhibited, that is, there were improvements in the fermentative profile and reduction in nutritional losses. 


\section{ENZYMES}

The ensiling process aims to preserve the quality of the forage so it is as similar as possible to the nutritional profile of the original forage, but most of the silage forages are rich in soluble carbohydrates and lactic acid, which makes them susceptible to aerobic deterioration during the silos unloading. Thus, to reduce nutrient losses during the fermentation process of the silage, to preserve its nutritive value, to optimize the fermentation process, to reduce aerobic deterioration and to increase aerobic stability during the supply in the trough, numerous researches have been developed with the use of biological additives and have shown satisfactory results with additives classified as silage fermentation stimulant products, containing cultures of specific bacteria or enzymes (BONALDI et al., 2017), where, among the most widely used types of enzyme in the silage process are cellulases, hemicellulases, amylases and pectinases (BONALDI, 2017; ZANETTE et al., 2012).

Lynd et al. (2002) point out that life on our planet is dependent on photosynthesis, which results in a production of plant biomass that has as its main component the cellulose, and in addition, the microorganisms that use cellulose present in the soil and in the intestines of the animals cause the closing up of the carbon cycle, since only they are able to make this process cyclical. Microbial cellulose appears to be an important source of protein in the ruminant diet, and because of the vast supply and relatively low costs, cellulosic materials become a particularly attractive resource.

However, there are some technological barriers to further expansion of the use of this important resource, and this is due to the general absence of low-cost technology to overcome the recalcitrance of cellulosic biomass. A promising strategy pointed out by the author to overcome this impediment, involves the production of cellulolytic enzymes, hydrolysis of the biomass and fermentation of the resulting sugars into the desired products in a single step of the process by a microorganism or cellulolytic consortium (LYND et al., 2002).

The cellulose can be hydrolyzed in a coordinated and efficient way by the action of cellulolytic enzymes, such as endoglucanases, exoglycanases and $\beta$-glycosidases, (LYND et al., 2002); these being some of the cellulases that can be used in silages for cellulose degradation. These enzymes belong to the class of hydrolases and are highly specific biocatalysts that act on cellulosic materials, promoting their hydrolysis for the release of sugars (BONALDI, 2017).

Corn appears on the world stage as the most used forage crop for the production of silage, due to its high productivity, nutritional value and energy concentration. Using enzymes in its ensiling process, that act breaking the cellular wall and the starch of the grains, transforming 
them into simpler carbohydrates, facilitates the use by the lactic bacteria, increasing the fermentation of the silage and the efficiency of utilization animal. Another benefit from the use of enzymes in the silage is the reduction of the neutral detergent fiber and acid detergent fiber contents of the forage, thus reducing the indigestible fibrous components of the feed, and increasing the dry matter digestibility when consumed by the animals (BONALDI et al., 2017).

The main reasons for using enzymes that digest fibers in silage are the fact that the partial digestion of the plant's cell wall (cellulose and hemicellulose) produces soluble sugars that can be fermented by the LAB to decrease the $\mathrm{pH}$ of the silage, and as the fact that the partial digestion of the plant's cell wall can promote an improvement in the rate or extent of digestibility (KUNG JUNIOR, 2010).

Cysneiros et al. (2006) evaluating the effect of fibrolytic enzymes on the chemical composition of corn silage, verified a reduction of the neutral detergent insoluble fiber of the silage. This response can be explained based on the profile of the enzymatic activities, which demonstrated high cellulase and xylanase activities (enzymes involved in cell wall degradation), that showed response effectiveness in the reduction of the fiber to a level of $10 \mathrm{mg} / \mathrm{kg}$ as fed. The authors concluded that the silage submitted to the action of enzymes suffered a previous digestion, leading to a change in the fermentation pattern, but that does not mean, however, that it has more digestible fiber.

The application of enzymes stands out when it comes to routes that allow improvement in the digestibility of the vegetable organic material, which means to improve the digestion of lignocellulosic compounds. Therefore, the enzymatic availability in the ensiled material would increase its digestibility and increase the conversion efficiency by $100 \%$. A number of effects can be expected from the application of enzymes in the silage: increased conversion of less digestible compounds to biogas, acceleration of biogas formation and, finally, decrease in the viscosity of the treated raw material (QUIÑNES et al., 2012).

Enzymes are proteins that help in the metabolic processes, as an additive stimulant of the fermentation that has been gaining prominence in the production of silages. Amylase is an enzyme used to break down the starch into sugars and cellulases or xylanases, to degrade cell walls of the plant into sugars, since the sugars released after breaking down by the enzymes stimulate the growth of the silage bacteria and, in some cases, the enzymes that degrade the fibers also increase the forage digestibility (ADESOGAN, 2014).

\section{CHEMICAL ADDITIVES AND CHEMICAL ABSORBENTS}


Sousa et al. (2008) working with chemical additives and microbial inoculants in sugarcane silages, compared urea, L. buchneri and an inoculant combination with L. buchneri and P. pentosaceus, and observed that the result of this combination of inoculants provided a greater recovery of DM, higher in vitro digestibility of the DM and lower concentrations of ethanol, while L. buchneri alone produced characteristics similar to untreated silage.

Balieiro Neto et al. (2009) questioned that there is a tendency in most studies with sugarcane silage to be detained in the effect of the additives on the fermentation process and on the chemical composition of the silage produced, however, the reduction of losses and improvements in the quality of the silage alone cannot be identified as possible viable effects on the silage by the action of an additive. Its viability is verified through the production of digestible energy of sugarcane when used in the form of silage or in natura, thus, it is possible to consider the quali-quantitative criteria.

The use of chemical additives also promotes great benefits to the production of quality silage. Sodium benzoate, for example, is an acid additive that can be used in the production of silages. Ribeiro et al. (2009), using silage of Marandu grass, observed that benzoate was responsible for the reduction of the silage $\mathrm{pH}$ and the higher levels of lactic acid, which proves that this additive does not restrict the activity of acidolactic bacteria, besides being probable that the action of undesirable microorganisms such as enterobacteria and bacteria of the genus Clostridium was partially inhibited, which led to a greater preservation of the soluble carbohydrates of the silage.

Clostridia and enterobacteria may be rapidly inhibited by the addition of organic acids by quickly reducing the $\mathrm{pH}$ of the forages; such acids include propionic, benzoic, sorbic, formic and others. Propionic acid is one of the most used acids in silage preservation in the United States because its dissociated form has antifungal effect, and the lower the $\mathrm{pH}$, the more effective the acid will be (ADESOGAN, 2014). This effect is beneficial both during the fermentation process and after, due to the higher aerobic stability of the material favored by the action of this acid in the medium.

Micro pulverized virgin lime or calcium oxide can be used as silage additives, and these products are applied to sugarcane silages in order to reduce alcoholic fermentation by partially solubilizing hemicellulose (FABRIS et al., 2013). However, Custódio et al. (2016) demonstrated that calcium oxide greatly increased the buffer capacity and led to poor quality sugarcane silages. This explanation was attributed to the lack of coherence between good nutritional composition and performance of the animals that were fed sugarcane treated with calcium oxide (JACOVACI et al., 2017). 
The same authors working with the addition of calcium oxide in sugarcane silage, demonstrated that calcium oxide decreased ethanol formation and improved nutrient recovery and aerobic stability, while consistently led to butyric fermentation, reflecting in a low animal performance, since the best preservation of the nutrients are not reflected in higher performance, and the use of calcium oxide alone in sugarcane silage is not recommended.

\section{NUTRITIONAL ADDITIVES AND NUTRITIONAL ABSORBENTS}

One of the most recommended and used techniques to control silage effluent production is the use of moisture-absorbing additives, since in addition to increasing DM content, it is possible to increase the nutritive value of the silage, and to provide soluble carbohydrates, which improve the quality of the fermentation in the silo and have high absorbent capacity (Pires et al., 2009; Tavares et al., 2009).

The effluent losses are related to several factors, such as the water activity that is associated with the DM content of the ensiled forage, the physical treatment applied to the forage at the moment of cutting and the use of additives (ITAVO et al., 2010). Schmidt (2008), makes it clear that the main factors that condition the use of additives in silages are the reductions in the losses of DM, the increase in nutritive value or the improvement in aerobic stability of the final product.

In addition, agricultural and agroindustry residues appear as an alternative of potential application in livestock, with the purpose of reducing costs, mainly in the states and producing regions, adding value to this available raw material and improving fermentative characteristics of the silages. Ferreira et al. (2009), indicated that when using industrial by-products, a prior evaluation of the effects of these by-products on consumption and animal digestibility is required, since performance will be affected.

Bonaldi (2017) points out that in addition to the possibilities of using enzymes as potential biological inoculants, the use of agroindustry residues as a source of carbon and enzymatic inducer in fermentative processes has been proposed and it is increasing. There is a wide range of by-products from agroindustry activities that are likely to be used to improve the fermentation process, such as rice and wheat straw, wheat, corn and rice bran; sugarcane and orange bagasse, banana and corn ear residue, whey, molasses, water from the maceration of corn and pulp and coffee husk.

Silva et al. (2010), nutritionally characterizing the silage from the pupunha by-product, added with cassava meal, corn meal, palm oil cake and urea (nutrient absorbent additives), observed that in the silage of pupunha by-product with $10 \%$ of cassava meal (residue from the 
bark and dehydrated cassava cuttings), presented the best fermentation characteristics during the ensiling process and best nutritional value, besides being characterized as an alternative source of roughage.

Large losses of dry matter can be observed in the silo when grasses are harvested and ensiled with excessive moisture, and they may be even greater due to the occurrence of butyric fermentation, usually caused by clostridia, and characterized by a great loss of energy (BARCELOS et al., 2018).

Pires et al. (2009) cite the coffee husk, cocoa meal and cassava meal as potential absorbent additives for use in ruminant feeding, and demonstrated that the use of these additives in elephant grass silage presented adequate fermentation characteristics, however, both coffee husk and cocoa meal reduced the nutritive value of the silage, occurring the contrary when using cassava meal, which reduced the components of the cell wall and increased the in vitro digestibility of the dry matter of the silages.

There is a certain difficulty in ensiling sugarcane because this crop is susceptible to secondary fermentations, producing ethanol (alcohol), by the activity of yeasts that use sugars for their growth, but the adoption of appropriate management techniques can solve this problem, thus, the viability of the production of sugarcane silage will only be possible with the use of additives capable of controlling the alcoholic fermentation. For this reason, the use of dehydrated barley residue appears as a suitable alternative to be used as a moisture sequestrant in sugarcane silage, contributing to reduce gas or effluent losses, limiting the action of bacteria of the genus Clostridium and improving the nutritional quality of the ensiled material (CASTRO et al., 2015).

The citrus pulp appears as another source of absorbent additive that has been widely diffused in the inclusion of experimental diets, observed in several works in the literature, as well as in several farms. Besides promoting absorption of effluents this additive is also an energetic ingredient that adds a higher nutritional value to the silage. Tavares et al. (2009) used citrus pulp as a moisture-absorbing additive in tanzania grass silage and observed improvements in silage digestibility due to the fact that the it reduced the levels of neutral detergent insoluble fiber and acid detergent insoluble fiber and increased the levels of crude protein, besides promoting more favorable conditions to the fermentative profile, reducing proteolysis through a more pronounced reduction of $\mathrm{pH}$.

Ferreira et al. (2009) evaluating the nutritional value of the by-product from the pineapple agroindustry as an additive in elephant grass silage, observed that the dry matter intake increased as the dehydrated by-product from the pineapple was added. This increase in DM intake by the animals may be related to the increase in the DM content of the silages, since the feed intake is 
related to the moisture of the diet, as a function of the moisture proportions contained in the feeds that will determine the space occupied in the rumen. For that reason, Soares et al. (2012) showed that the addition of the dehydrated by-product from the pineapple processing in the elephant grass silage, by improving the fermentation process and reducing the moisture content of the silages causes an increase in the consumption. However, dietary neutral detergent insoluble fiber content should be considered, as Castro et al. (2015) reported that the progressive increase of fiber may imply a reduction in dry matter intake due to the decrease in the rate of passage of the feed through the digestive tract which causes a physical effect of filling the rumen by the excessively fibrous material.

There are several benefits from the use of agroindustry by-products and residues for animal production, such as in the case of fruit processing, where its use can lead to a reduction in the costs of animal production, since the feeding makes up to $70 \%$ of the costs of this activity. In addition, several studies have shown that, at appropriate levels, calculated on the basis of their chemical-bromatological composition, fruit by-products can substitute forage feeds and even traditional concentrates such as corn and soybean meal (CRUZ et al., 2013).

Bonfá et al. (2017) also point out that the use of agroindustry residues destined for animal feeding makes it possible to remove from the environment potential environmental impact causing agents and, also, it is possible to obtain better quality roughage for ruminant feeding. As agroindustry residues act as an alternative and low-cost substrate for fermentation, they also reduce the environmental problems caused by their inadequate disposal in the environment and directly by reducing the production of effluents in the silages that they are added (BONALDI, 2017).

These possibilities can be used in several Brazilian regions, since Brazil is a tropical country and produces a large variety of fruits, along with the fact that there are several agroindustries spread throughout all regions of the national territory, guaranteeing in many cases, greater availability of food and possible increase in production efficiency (Cruz et al., 2013).

\section{FINAL CONSIDERATIONS}

It is essential to search for additives that bring benefits to the fermentation process, by reducing losses, stimulating or inhibiting fermentations, maintaining the forage stability, preserving the nutritive value of the ensiled mass so that it is similar to the green forage, or as close as possible to the plant it came from, or by adding nutritional value through certain classes of additives. 


\section{REFERENCES}

ADESOGAN, A. T. Avoiding the two greatest silage problems. In: Proceedings. Gainesville: 50th Florida Dairy Production Conference, p. 9-17, 2014.

BALIEIRO NETO, G. et al. Perdas fermentativas, composição química, estabilidade aeróbia e digestibilidade aparente de silagem de cana-de-açúcar com aditivos químico e microbiano.

Pesquisa Agropecuária Brasileira. v. 44, n. 6, p. 621-630, 2009.

BARCELOS, A.F. et al. Valor nutritivo e características fermentativas da silagem de capimelefante com diferentes proporções de casca de café. Ciência Animal Brasileira. v. 19, e-27432, 2018. Disponível em: http://dx.doi.org/doi:10.1590/1809-6891v19e-27432

BASSO, F.C. Estabilidade Aeróbia de Silagens de Planta e de Grãos Úmidos de Milho. Jaboticabal: UNESP, 2009. 80 p. Dissertação (Mestrado em Zootecnia) - Universidade Estadual Paulista "Júlio de Mesquita Filho" Faculdade de Ciências Agrárias e Veterinárias, Jaboticabal, 2009.

BASSO, F.C. et al. Características da fermentação e estabilidade aeróbia de silagens de milho inoculadas com Bacillus subtilis. Revista Brasileira de Saúde Produção Animal, v. 13, n. 4, p.1009-1019, 2012.

BERNARDES, T.F.; AMARAL, R.C. Como e quando aplicar o aditivo na ensilagem? Milkpoint, 17 jan. 2008. Disponível em: <https://www.milkpoint.com.br/artigos/producao/comoe-quando-aplicar-o-aditivo-na-ensilagem-42183n.aspx >. Acesso em: 29 junh. 2019.

BONFÁ, C.S. et al. Silagem de capim-elefante adicionada de casca de abacaxi. Revista Ceres. 2017, v .64, n. 2, p.176-182, 2017. Disponível em: http://dx.doi.org/doi:10.1590/0034737X201764020010.

BONALDI, D.S. Inoculação de Bacillus subtilis e seus metabólitos em silagem de milho. Lavras: UFLA, 2017. 47 p. Dissertação (Microbiologia Agrícola) - Universidade Federal de Lavras, Lavras, 2017.

CARVALHO, B.F. et al. Microbiological and chemical profile of sugar cane silage fermentation inoculated with wild strains of lactic acid bacteria. Animal Feed Science and Technology, v. 195, p. 1-13. 2014. Disponível em: http://dx.doi.org/doi:10.1016/j.anifeedsci.2014.04.003.

CASTRO, W.J.R. et al. Silagem de cana-de-açúcar aditivada com resíduo de cervejaria desidratado. Scientific Electronic Archives, v. 8, p. 1-10, 2015.

CRUZ, S.S. et al. Resíduos de frutas na alimentação de ruminantes. Revista Eletrônica Nutritime, v. 10, p. 2909-2931, 2013.

CUSTÓDIO, L. et al. Effects of chemical and microbial additives on clostridium development in sugarcane (Saccharum officinarum L.) ensiled with lime. Grassland Science, 62, 135-143, 2016. Disponível em: http://dx.doi.org/doi:10.1111/grs.12124

CYSNEIROS, C. et al. Efeito de enzimas fibrolíticas sobre a composição química da silagem de milho. Ciência Animal Brasileira, v. 7, n. 4, p. 339-348, 2006. 
DUNIERE, L. et al. Impact of adding Saccharomyces strains on fermentation, aerobic stability, nutritive value, and select lactobacilli populations in corn silage. Journal of Animal Science, v. 93, 2015. Disponível em: http://dx.doi.org/doi:10.2527/jas.2014-8287

FABRIS, L.B. et al. Composição bromatológica da silagem de dois cultivares de cana-de-açúcar tratadas com doses crescentes de cal virgem. Revista Agrarian, v. 6, n. 21, p. 333-339, 2013.

FERREIRA, A.C.H. et al. Avaliação nutricional do subproduto da agroindústria de abacaxi como aditivo de silagem de capim-elefante. Revista Brasileira de Zootecnia, v. 38, n. 2, p.223-229, 2009. Disponível em: http://dx.doi.org/10.1590/S1516-35982009000200002.

FERREIRA, D.J. et al. Silage fermentation and chemical composition of elephant grass inoculated with rumen strains of Streptococcus bovis. Animal Feed Science and Technology, v. 183, n. 1-2, p. 22-28, 2013. Disponível em: https://doi.org/10.1016/j.anifeedsci.2013.04.020.

FERREIRA, D.J. et al. Chemical composition and nutrient degradability in elephant grass silage inoculated with Streptococcus bovis isolated from the rumen. Anais da Academia Brasileira de Ciências, v. 86, n. 1, 465-473, 2014. Disponível em: http://dx.doi.org/10.1590/0001-

$\underline{37652014112312 .}$.

FERREIRA, D.J. et al. Perfil fermentativo e valor nutritivo de silagem de capim-elefante inoculada com Streptococcus bovis. Archivos de Zootecnia, v. 60, p. 1223-1228, 2011. Disponível em: http://dx.doi.org/doi:10.4321/s0004-05922011000400037.

HUISDEN C.M. et al. Effect of applying molasses or inoculants containing homofermentative or heterofermentative bacteria at two rates on the fermentation and aerobic stability of corn silage. Journal of Dairy Science, v. 92, p. 690-697, 2009. Disponível em:

https://doi.org/10.3168/jds.2008-1546.

ÍTAVO, L.C.V.; ÍTAVO, C.C.B.F. Estratégias para o uso de subprodutos da agroindústria associados às silagens. In: JOBIM, C.C, CECATO, U., CANTO, MW. (Orgs). Produção e utilização de forragens conservadas, p.153-195, 2008.

ÍTAVO, L.C.V. et al. Composição química e parâmetros fermentativos de silagens de capimelefante e cana-de-açúcar tratadas com aditivos. Revista Brasileira de Saúde e Produção Animal, v. 11, p. 606-617, 2010.

JACOVACI, F.A. et al. A data-analysis on the conservation and nutritive value of sugarcane silage treated with calcium oxide. Animal Feed Science and Technology, v. 225, n. 1-7, 2017. Disponível em: https://doi.org/10.1016/j.anifeedsci.2017.01.005.

JOBIM, C.C.; NUSSIO, L.G. Princípios básicos da fermentação na ensilagem. In: REIS, R.S; BERNARDES, T.F.; SIQUEIRA, G.R. Forragicultura: ciência, tecnologia e gestão dos recursos forrageiros. Seção, 11 - Forragem conservada, p. 814-833, 2014.

JONES, B.A.; HATFIELD, R.D.; MUCK, R.E. Effect of fermentation and bacterial inoculation on lucerne cell walls. Journal of the Science of Food and Agriculture, v. 60, n. 2, 147-153, 1992. Disponível em: http://dx.doi.org/doi:10.1002/jsfa.2740600203

KUNG JÚNIOR, L. A Review on Silage Additives and Enzymes. Department of Animal and Food Sciences University of Delaware Newark, DE 19717-1303, 2010. 
KUNG JÚNIOR, L. Aerobic stability of silages. Proceedings of the 2nd International Symposium on Animal Production under Grazing, 2., Viçosa. Proceedings... [s.n.], p. 233-248, 14 p. 2008.

LANNA FILHO, R.; FERRO, H.M.; PINHO, R.S.C. Controle biológico mediado por Bacillus subtilis. Revista Trópica: Ciências Agrárias e Biológicas, v. 4, n. 2, p.12- 20, 2010. Disponível em: http://dx.doi.org/10.0000/rtcab.v4i2.145

LARA, E.C. et al. Changes in the nutritive value and aerobic stability of corn silages inoculated with Bacillus subtilis alone or combined with Lactobacillus plantarum. Animal Production Science, V. 56, p. 1867-1874, 2015. Disponível em: https://doi.org/10.1071/AN14686

LYND, L.R. et al. Microbial Cellulose Utilization: Fundamentals and Biotechnology. Microbiology and Molecular Biology Reviews, v. 66, p. 506, 2002. Disponível em: http://dx.doi.org/doi:10.1128/mmbr.66.3.506-577.2002

LOPES, J; EVANGELISTA, A.R. Características bromatológicas, fermentativas e população de leveduras de silagens de cana-de-açúcar acrescidas de ureia e aditivos absorventes de umidade.

Revista Brasileira de Zootecnia, v. 39, n. 5, p. 984-991, 2010. Disponível em: http://dx.doi.org/10.1590/S1516-35982010000500007.

MANTOVANI, H.C.; WOROBO, R.W.; RUSSEL, J.B. Bovicin HC5, a bacteriocin from Streptococcus bovis HC5. Microbiology, v. 148, p. 3347-3352, 2002. Disponível em: http://dx.doi.org/doi:10.1099/00221287-148-11-3347

MARI, L.J. Uso de inoculantes em silagens de milho (e sorgo): quais os benefícios?

MILKPOINT, 15 fev. 2016. Disponível em:

<https://www.milkpoint.com.br/empresas/novidades-parceiros/uso-de-inoculantes-em-silagensde-milho-e-sorgo-quais-os-beneficios-85646n.aspx $>$.

MENDES C.Q. et al. Efeito do Lactobacillus buchneri na fermentação, estabilidade aeróbia e no valor nutritivo de silagem de cana-de-açúcar. Revista Brasileira de Zootecnia, v. 37, n. 12, p. 2191-2198, 2008. Disponível em: http://dx.doi.org/10.1590/S1516-35982008001200017

MOHALLEM, R.F.F.; MOHALLEM, D.F.; OLIVEIRA, M.V. Hidróxido de cálcio (Ca (OH)2) e bactérias heterofermentativas como aditivos em silagens de cana-de-açúcar (Saccharum officinarum L.) e seus efeitos sobre a composição bromatológica e dinâmica fermentativa. Enciclopédia Biosfera. v. 9, p. 1242-1259, 2013.

MUCK R.E. et al. Silage review: recent advances and future uses of silage additives. Journal of Dairy Science, v. 101, n. 5, p. 3980-4000, 2018. Disponível em:

https://doi.org/10.3168/jds.2017-13839

MUCK, R.E. Silage microbiology and its control through additives. Revista Brasileira de Zootecnia, v. 39, p. 183-191, 2010. Disponível em: http://dx.doi.org/10.1590/S1516$\underline{35982010001300021}$

MUCK, R.E. et al. Silage review: Recent advances and future uses of silage additives. Journal of Dairy Science, v. 101, n. 5, p. 3980-4000, 2018. Disponível em:

https://doi.org/10.3168/jds.2017-13839 
OGUNADE, I.M. et al. Silage review: Mycotoxins in silage: Occurrence, effects, prevention, and mitigation. Journal of Dairy Science, v.101, n. 5, p. 4034-4059, 2018. Disponível em: https://doi.org/10.3168/jds.2017-13788

OLIVEIRA, L.S. et al. Caracterização nutricional de silagens do coproduto da pupunha. Revista Brasileira Saúde Produção Animal, v. 11, n. 2, p. 426-439, 2010.

OLIVEIRA, M.R. et al. Uso de aditivos biológicos na ensilagem de forrageiras. Ambiência Guarapuava, v. 7, n. 3, p. 589-601, 2011. Disponível em: http://dx.doi.org/doi:10.5777/ambiencia.2011.03.01rb

OLSTORPE, M. et al. Pichia anomala yeast improves feed hygiene during storage of moist crimped barley grain under Swedish farm conditions. Animal Feed Science and Technology, v. 156, n. 1-2, p. 47-56, 2010. Disponível em: https://doi.org/10.1016/j.anifeedsci.2009.12.008

PAHLOW, G. et al. Microbiology of ensiling. Silage Science and Technology, n. 42, p.1-62, 2003. Disponível em: http://dx.doi.org/doi:10.2134/agronmonogr42.c2

PIRES, A.J.V.; CARVALHO, G.G.P.; GARCIA, R. Capim-elefante ensilado com casca de café, farelo de cacau ou farelo de mandioca. Revista Brasileira de Zootecnia, v. 38, n. 1, p. 34-39, 2009. Disponível em: http://dx.doi.org/10.1590/S1516-35982009000100005.

QUIÑONES, T.S. et al. Hydrolytic Enzymes Enhancing Anaerobic Digestion. Biogas Production, p. 157-198, 2012. Disponível em: https://doi.org/10.1002/9781118404089.ch6

RIBEIRO, J.L. et al. Efeitos de absorventes de umidade e de aditivos químicos e microbianos sobre o valor nutritivo, o perfil fermentativo e as perdas em silagens de capim-marandu. Revista Brasileira de Zootecnia, v. 38, n. 2, p. 230-239, 2009. http://dx.doi.org/10.1590/S151635982009000200003.

SANTOS, A.O. Seleção e avaliação de cepas bacterianas para ensilagem de milho. Lavras: UFLV, 2012. 167 6tp. Dissertação (Mestrado em Zootecnia) - Universidade Federal de Lavras, Lavras, 2012.

SANTOS, E.M.; ZANINE, A.M. Silagem de gramíneas tropicais. Colloquium Agrariae, v. 2, n.1, p. 32-45, 2006. Disponível em: http://dx.doi.org/doi:10.5747/ca.2006.v02.n1.a21

SCHMIDT, P. Aditivos químicos e biológicos no tratamento de cana-de-açúcar para alimentação de bovinos. In: JOBIM, C.C.; CECATO, U.; CANTO, M.W. (Ed.). In: Simpósio Sobre

Produção e Utilização de Forragens Conservadas, 3., 2008, Maringá. Anais... Maringá: UEM, p.117-152, 2008.

SCHMIDT, P.; SOUZA, C.M.; BACH, B.C. Uso estratégico de aditivos em silagens: Quando e como usar? Simpósio: Produção e Utilização de Forragens Conservadas, 5.ed., Maringá, 2014. Anais... Maringá: UEM, p.243-264, 2014.

SIQUEIRA, G.R. et al. Burning and chemical and bacterial additives in sugar cane silage. Revista Brasileira de Zootecnia, v. 39, p. 103-112, 2010. Disponível em: http://dx.doi.org/doi:10.1590/S1516-35982010000100014 
SOARES B.C. et al. Desempenho e características de carcaças de cordeiros suplementados com diferentes níveis de resíduo de biodiesel. Arquivo Brasileiro Medicina Veterinária e Zootecnia, v. 64, n. 6, p.1747-1754, 2012. Disponível em: http://dx.doi.org/10.1590/S010209352012000600046.

SOFYAN, A. et al. Microbiological characteristic and fermentability of king grass (Pennisetum hybrid) silage treated by lactic acid bacteriayeast inoculants consortium combined with rice bran addition. Jouran Indonesian Tropical Animal Agricultural, v. 36, n. 4, p. 265-272, 2011. Disponível em: http://dx.doi.org/doi:10.14710/jitaa.36.4.265-272

SOUSA, D.P. et al. Efeito de aditivo químico e inoculantes microbianos na fermentação e no controle da produção de álcool em silagens de cana-de-açúcar. Revista Brasileira de Zootecnia, v. 37, n. 9, p. 1564-1572, 2008. Disponível em: http://dx.doi.org/10.1590/S1516$\underline{35982008000900007}$

SOUSA, D.P.; SILVA, J.A.; OLIVEIRA, I.S. Uso de Aditivos em Forragens Conservadas. I SIMPÓSIO MATOGROSSENSE DE BOVINOCULTURA DE CORTE, 1., Cuiabá, 2011, Anais... Cuiabá: Universidade Federal de Mato Grosso, 2011. p. 1-48.

TABACCO, E. et al. Clostridia spore formation during aerobic deterioration of maize and sorghum silages as influenced by Lactobacillus buchneri and Lactobacillus plantarum inoculants. Journal of Applied Microbiology, v. 107, n. 5, p. 1632-1641, 2009. Disponível em: http://dx.doi.org/doi:10.1111/j.1365-2672.2009.04344.x

TAVARES, V.B. et al. Efeitos da compactação, da inclusão de aditivo absorvente e do emurchecimento na composição bromatológica de silagens de capim-tanzânia. Revista Brasileira de Zootecnia, v. 38, n. 1, p. 40-49, 2009. Disponível em: http://dx.doi.org/10.1590/S1516-35982009000100006

TODOVORA, S; KOZHUHAROVA, L. Characteristics and antimicrobial activity of Bacillus subtilis strains isolated from soil. Journal of Microbiology and Biotechnology, v. 96, p. 11511161, 2009. Disponível em: http://dx.doi.org/doi:10.1007/s11274-009-0290-1

YITBAREK, M.; TAMIR, B. Silage Additives: Review. Open Journal of Applied Sciences, 4, p.258-274, 2014. Disponível em: http://dx.doi.org/10.4236/ojapps.2014.45026

ZANETTE, P.M. Efeito da inclusão de açúcar ou inoculante bacteriano na silagem de milho sobre perdas, valor nutricional, desempenho e eficiência econômica de novilhos confinados. Guarapuava: UNICENTRO, 2010. 119p. Tese (Mestrado em Produção vegetal) - Universidade Estatual do Centro-Oeste, Guarapava, 2010.

ZOPOLLATTO, M.; DANIL, J.L.P.; NUSSIO, L.G. Aditivos microbiológicos em silagens no Brasil: revisão dos aspectos da ensilagem e do desempenho de animais. Revista Brasileira de Zootecnia, v. 38, p. 170-189, 2009. Disponível em: http://dx.doi.org/10.1590/S1516$\underline{35982009001300018}$ 